\title{
The Conflict of Theory in Arabic Grammar
}

\author{
Solehah Hj Yaacob
}

\begin{abstract}
There have been debates and discussions on linguistics`argumentations used by both schools Basra and Kufa in order to impose their principles in modification of Arabic Grammar. This kind of scenario contributes some negatives and positives views among the scholars claimed that BaÎra and Kufa were the two cities which permanently rivaled each other. In principle, BaÎra and Kufah do evidence two differing linguistic and grammatical approaches. The school of Basra was generally more philosophically inclined when formulating the system of Arabic grammar while the school of Kufah based its rules on evidence found in classical texts. Although Basra applied more analogy does not mean that Basran scholars did not also refer to the already existent linguistic corpus in the classical texts. In order to re-evaluate the above discussion, the researcher addresses some evidences from the linguistic corpus and analogical approach in Arabic Grammar.
\end{abstract}

Index Terms-Rival, analogical, anomaly, corpus.

\section{INTRODUCTION}

Classical Arabic had eight cases: accusative (nasab), genetive (jar), nominative ( raf Ñ), apocopate (jazm), a-vowel (fath), i-vowel (kasr), u-vowel (İam) and zero-vowel (waqf). Sibawayh divided the endings of the eight cases into four pairs: the accusative and a-vowel, the genitive and i-vowel, the nominative and $\mathrm{u}$-vowel, and lastly the apocopate and zero-vowel. A word which receives different pairs because it is produced by a governor, its ending is not permanent and will be changed based on its position and use in the sentence. This system can be called the process of governing or the concept of al-Ñamil. ShawqÊ Öaif believed this kind of rule was unique to Arabic grammar ${ }^{1}$ and a sufficient proof of its originality. The introduction of short-vowel signs in written language has to be considered a separate development and does not interfere with the original syntax. Arabic as a complete and fully developed language already existed before the arrival of Prophet Ishmael used by the tribe QahÏÉn and HimyÉr. Arabic was the language spoken by a tribal leader called Jurhum who married the daughter of IrÉm, sÉm`s son after Noah's flood, and through his offspring Arabic became the language of a great nation ${ }^{2}$. The offspring of Ishmael arrived and spread the use of Arabic. Arabic was an original language with its unique system of grammar

Manuscript received June 10, 2013; revised August 11, 2013.

Solehah $\mathrm{Hj}$ Yaacob is with the Arabic Dept. Language \& Literature International Islamic University Malaysia (e-mail: solehah71@gmail.com). p. 20

ShawqÊ Öaif, al-MadÉris an-Nahwiyyah, Cairo: DÉr al-MÑÉrif, 1995,

${ }^{2}$ See the critique of the traditions relating to Jurhum and his offspring in the book of the Dutch scholar Dozy 1864:146 and ff. (in the chapter: 'De tweede Gorhoem"). see Golziher, History of Grammar Among the Arabs, p. 45 which was already developed thousand years before the rise of Greece. In order to faithfully reflect the transmission process of Arabic we have to concentrate on early manuscripts. However the conflict among the traditional Arab schools of grammar indicated that the differences in intellectual approaches occurred in modifying the Arabic Grammar system. For example, the BaÎra School used philosophical and logical approaches in their analysis, critique, and in modifying and replacing the Arabic Grammar system. Contrary, the KËfah School concentrated on reading the Holy QurÉn, adÊth and Arabic poetry. ÑÓsim bin AbÊ NujËd, Hamzah ZayyÉt and KisÉ'Ê, who were from the QurrÉ' SabÑah, were also among the thinkers of the school. They worked on hypothetical and contemporary cases [which required analogy].

The aforementioned views have been discussed and clarified by some researchers, historians, linguists and grammarians. They established that the BaÎra School based their approach on analogy and the KËfa School based their approach on anomaly. However, this research aims to verify the approach of the BaÎra and KËfa Schools in order to investigate their principles in implementing the linguistic argumentation.

\section{THE RivalRY BeTWEen THE TWO SCHOOLS}

The KËfah School split from the BaIra school due to the dispute between Sibawayh and KisÉ 'i, concerning the case of ZanbËriah [1]. The different views regarding a grammar system continued until the arrival of FarÉ', who based most of his analysis on analogy. Many historians of linguistics assert that he was influenced by BaIrran scholars, but this claim has been refuted by ShawqÊ Öaif [2], who argued that Fara' was an independent scholar and original in his thought. However, when reviewing the sources, which Sibawayh referred to in his KitÉb, we have to agree that some of them were from the KËfah School [3]. There is no doubt that there was a substantial exchange of ideas between the scholars of KËfah and BaÎrah, as for FarÉ', who was considered the leader of the KËfan School, was found with Sibaway's Al-KitÉb under his pillow, [4] at the time of his death. Thus, to suggest that BaÎra was completely free from KËfan ideas is erroneous. The analogists' system of grammar needs to be verified using the anomaly approach such as Sibawayh and JumhËr al-Nuhah allowed the use of the samÉÑ system in the topic of ÍÉl (condition) [5]. Both agreed that the word بغتخ in زيَيّْ طلعَ بغتَّة (Zayd appeared suddenly) is a gerund-describing form. In another case, they accepted the qirE' 'ah shÉdhah in

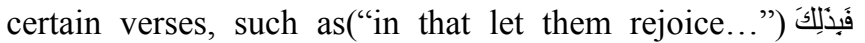

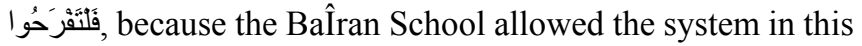

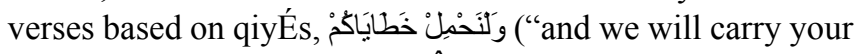
sins"). This means that the Bâ̂ran scholars used analogy. A 
number of propagators of anomaly accepted the use of analogy in some cases, for example, with reference to $\operatorname{tawk} \hat{E} d$,

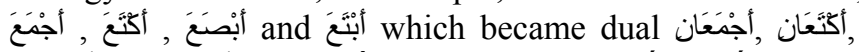

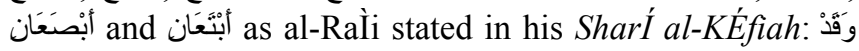

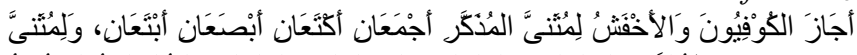

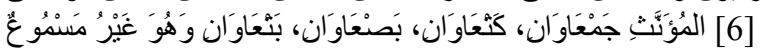

Another case is their acceptance of the accusative case in fiNil muĺÉriÑ (present and future tense verb) such as ليكونَ, is

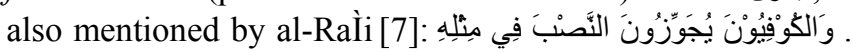
قِيَاسأ (And the KËfans permit this particular verb or the like of it, to take the accusative case based on qiyÉs (analogy).

In this regard, Ignaz Goldziher made the following observation: "I would like to highlight one which provides in itself a very ample source for the study of the theoretical tendencies of the two schools, this is the book of Ibn al-AnbÉri entitled Al-InsÉf FÊ MasÉil al-KhilÉf Bayna

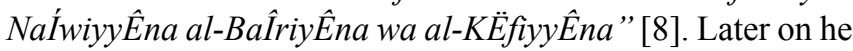
explains that the "two above-mentioned schools are distinguished by almost the same criteria that divide the analogists from the anomalists in the field of classical grammar" [9]. Ibn al-AnbÉri's work consists of 121 problems, which needs to be revised, and its content thoroughly analyzed. According to Gotthold Weil [10], the rival theory between BaÎra and KËfa has to be dismissed due to a lack of evidence that a full-fledged KËfan school actually existed. He argues that Ibn al-AnbÉri did not propagate KËfan thought because the latter only agreed with the KËfan scholars in four of his 121 cases [11]. Thus, it was more likely for the Kufans to seek answers and orientation from the BaÎrans, but the two schools were not on equal footing and thus could not have been rivals.

\section{ANALOGY AND ANOMALY AS LingUiSTIC ARGUMENTATIONS}

SaÑid JÉsim al-Zubayr [12] highlighted the importance of using qiyÉs (analogy) and sama'(anamoly) in Arabic grammar for the BaÎran and KËfan school by quoting

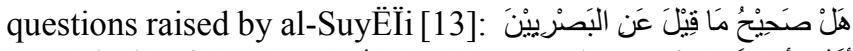

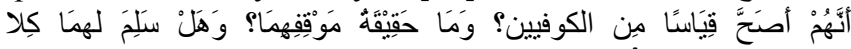
المَنَهَجَيْن؟ كَ (Is it correct to say that the BaÎrans are more analogical than the Kufans? What is their actual position (in grammar) and are both approaches acknowledged.) Shaykh ÙanÏÉwÊ [14] stressed the positive aspect of the different modes of approach of both schools. Ignaz Goldziher on the other hand claimed that BaÎra and Kufa were the two cities which permanently rivaled each other. He writes: "Just as they differ in character and political tendency, the two towns also differ in their treatment of the sciences, the opposition of the Bâ̂ran and Kufan schools is spoken of in all fields, they oppose each other in historical questions and in the science of traditions, differences between them are mentioned even concerning their dialects, but the most intense opposition between them concerns linguistic, and especially grammatical questions"3

He persisted in claiming that, "the Bâ̂ran School represents analogy, which likes to treat everything by the same standard, while the KËfan school represents the

\footnotetext{
${ }^{3}$ Ignaz Goldziher, History of Grammar Among The Arabs, pp.33
}

prerogative of individuality in grammar, and allows the regulation and arrangement of grammar. This is not only according to the forms that remain on the highroad of regularity, but also those forms which are used according to the individual will of poets" [15]. He continues: "What, quite wrongly, used to be called grammarians' 'exceptions 'are called by Arab grammarians', al-ShÉĐ (plur. as-ShawÉĐ), or properly speaking, isa form not conforming to grammatical analogy (al-qiyÉs), but which appears in ancient poetry", In response to the above mentioned allegations made by Goldziher, we ought to investigate how far the acceptance of analogy (qiyÉs) went in the BaÎran School. This has been illustrated by al-Akhfash al-AwsÉt who noted that Sibawayh accepted most of the qira'Ét القِرَاءَهُة لا نَخَالفُ، لأنها سُنّة (Al-QirÉ'ah does not violate (the grammar) because it is customary.) [16]. Let us examine some of the cases of analogy (qiyÉs), anomaly (samÉN $)$ and qira'Ét shÉdhah. Grammatical anomalies were found in the classical Arab

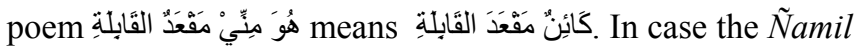

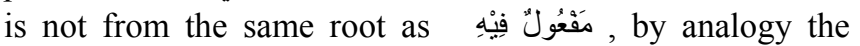

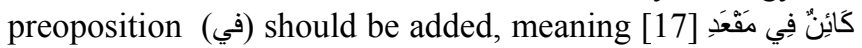
القابلةِة another case of anomaly [18].

) للك العزّ إنْ مَوْلاكَ عزَّ، وإنْ يُهُنْ * فأنت لدى بُحبوحةِ الهون كائنُ are great, if your lord is great \& if he is affluential then you are an affluent being)

The case study here is the existence of "كائئ , which cannot be regarded as a standard for forming the system of qiyÉs. In this regard, Golziher quoted SuyËÏÊ's opinion [19]: "One of the most well-known differences between the two grammatical schools is related to these ShawĖ. When the unimaginative BaÎIran grammarian comes across ShÉĐ, he holds his ground and asserts that such an exceptional form should remain what it is, that is, an exception which cannot be regarded as a standard for forming other words." [20]. Arab grammarians accepted the sama' used by KËfan scholars in order to support qiyas. For example, أمَيَّلح meaning 'to become smaller', however, it is not used as a verb but as a

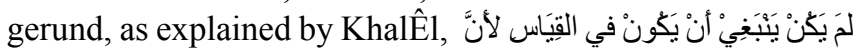
(This verb is not supposed to be analogically measured/analyzed because it is not degraded (unknown) but they degraded it. ) [21]. The manner (ÍÉl) in gerund form has also been accepted by Mubarrid who gives the example of, جَاءَ زَيدُ بغنتة the keyword being بغتة as a gerund in anomaly [22]:

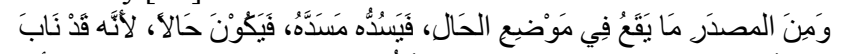

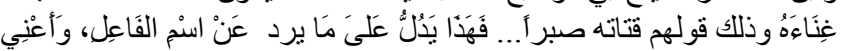

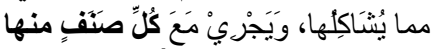

(The maÎdÉr- infinitive (verbal noun) can replace the ÍÉl because it represents the active participle, as in; (aÑnE ghinÉ'ahu and qatÉtuhu Îabran), this indicates conformity of each item). [23]

This is evidence that the BaÎran school accepted an abnormal (shÉdh) form based on the precedent فَبَلِلكَ فَلْتَّرَحُوْا where the existence of لأحُ الأمز before the pronoun is

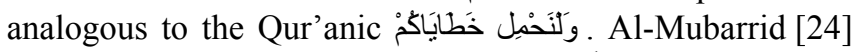

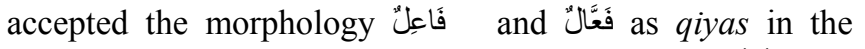

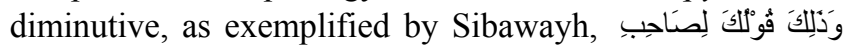

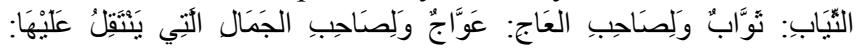




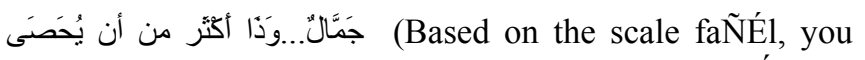
would refer to the one who owns dresses as a thawwÉb, the one who owns ivory would be an $\tilde{\mathrm{N}} a w w E j$ and the one who possesses beauty is known as jammÉl...( referring to one who owns an uncountable measure of something) [25]. There is an instance where the majority of scholars accepted a case

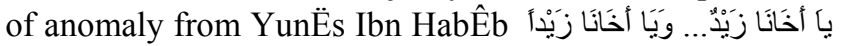
[26]. In this case, there are two possible ways of reading of 'Zayd', in the nominative and the accusative case. Both readings are acceptable.

In summary, is not exclusively the BaÎran School which applied the prerogative of originality in grammar generally represented by the KËfan school. KËfan grammarians like KisÉ' $i$ and FarÉ' are known to have used analogy ascribed to the BaÎran Øchool. This was already mentioned by SuyËÏ̂̂E

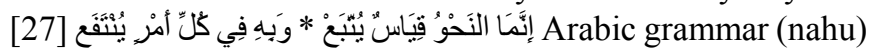
follows/is based on analogy \& it (analogy) can be used for everything).

MahdÊ al-MakhzËmÊ [28] supports SuyËt $\hat{E}$ in this matter

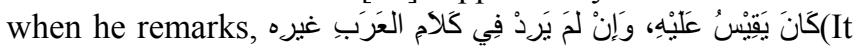
(Arabic grammar) was analogically measured if it (a case) was unknown to the Arabs). There are cases of analogy established by the KËfan school, such as the verb for $t a \tilde{N} a j u b$

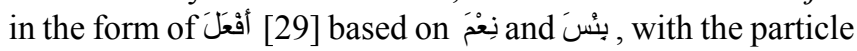
ن derived from $\gamma$ and [30]. Sa'id Jasim al-Zubayr, states in his al-QiyÉs f̂E al-Nahwi al-'ArabE - Nash'atuhu wa

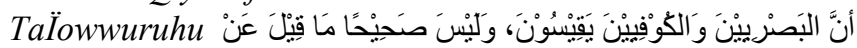

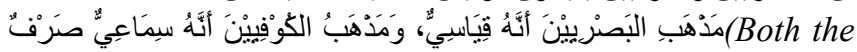
BaÎrans and the KËfans used an analogical approach in their rulings and the to state that the BaÎrans were analogists and the KËfans were propagators of anomaly (anomalists), is incorrect.) [31]. This idea is supported by MahdÊ al-MakhzËmÊ [32], who asserts that the Kufan school did not only distinguish themselves through the application of anomaly, but also through the intellectual aptitude of its grammarians. FarÉ', for example, based his grammatical principles on philosophy, and did not hesitate to formulate his own ideas on invisible ÑawÉmil, sometimes he refuted anomaly and used qiyÉs where he saw it appropriate [33]. Despite all textual, Golziher persisted in his theory of the two rivaling schools by referring to a completely separate field of scholarly enquiry, namely that of Islamic jurisdiction. He alleges the following: "On the basis of what I expounded in another study about the school of AbË HanEffa, the great jurist, it can very easily be understood why this ImÉm felt attracted to the KËfan school of grammar" [34]. His study of AbË HanÊfah's legal thought consisted of a very general comparison of its Bâ̂ran counterpart, such as their different views with regard to 'sale' البَيْعُ, which Goldziher only discussed preliminarily and without including a thorough study of the general principles of jurisdiction $(u s \ddot{E} l)$, or any detailed studies of more complex issues. The fact that KËfan scholars were generally more enthusiastic and industrious in the transmission of classical poetry than their BaÎran colleagues is irrelevant at this point. The issue here is whether the KËfan system could be utilized by future generations of scholars who referred to the transmitted poems as precedents, which thus furnish them with more examples for analogy and in the process extend grammatical knowledge. It is unquestionable that analogy also needs to be accompanied by anomalies, as stated here [35]:

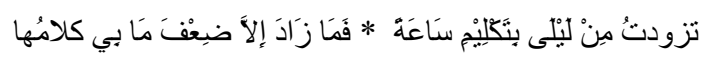

The case study here is ضعف Analogically it was

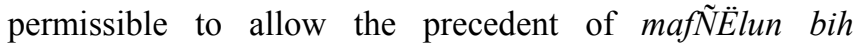

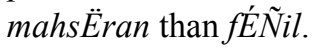

\section{CONCLUSION}

The evidence of opposing or differing views on grammar produced in BaÎra and KËfa does by no means necessitate the assumption that both schools were actively engaged in an intellectual battle with each other. Different methodologies and approaches did not develop isolated from each other but alongside each other. Different grammatical theories developed by KËfan and BaÎran grammarians did indeed complement each other, and not oppose each other.

\section{REFERENCE}

[1] S. Ê. Öaif, Grammar School, $6^{\text {th }}$ ed., Cairo: Library House, 1995, ch. 2 , pp. 174.

[2] S. E. Öaif, Grammar School, pp. 192-195.

[3] S. Éyh, The Book, $1^{\text {st }}$ ed., Emil Yaacob, Ed. Beirut: Scientific Library, 1999, vol. 1, ch. 2, pp. 38-122.

[4] A. T. A. LughawÊ, Grammarians Mattresses, $1^{\text {st }}$ ed., Cairo: Renaissance library, 1955, pp. 87.

[5] I. `AqÊl, Explain the Son of Aqil, $5^{\text {th }}$ ed. Y. S. M. A. BaqÉ Ê, Ed. Beirut: Thinker Library, 1998, vol. 1, pp. 500.

[6] A. RÉlì, A Complacent Explaination, $3^{\text {rd }}$ ed. Hassan Muhammad, Ed. Beirut: Scientific Library, 1986, vol. 1, pp. 334.

[7] A. RÉlì, A Complacent Explaination, $3^{\text {rd }}$ ed., vol. 1, final chapter on nawÉîib al-muliériñ.

[8] I. Goldziher, History of Grammar Among the Arabs, K. Devenyi and T. Ivanyi, ed. Netherlands: The John Benjamin Publishing Company, 1994, vol. 73 , ch. 3 , pp. 34.

[9] I. Goldziher, History of Grammar among the Arabs, pp. 35.

[10] The first editor of Fairness In Matters of Dispute Between Basra \& Kufa Grammarians and the first orientalist who doubted the existence of the School of KËfah, See ShawqÊ Öaif, Grammar School, pp. 155.

[11] S. E. Öaif, Grammar School, pp. 155.

[12] S. J. A. Zubayr, Measurement in Arabic Grammar, $1^{\text {st }}$ ed., 'AmmÉn: The Sunrise House, 1997, ch. 2, pp. 48.

[13] A. S. ËÏÊ, The Propose in the Science of Grammar, Beirut: Scientific Library, 1998, pp. 114.

[14] M. ÙanİÉwÊ, The Emergence of Grammar and History of The Most Famous Grammarians, $1^{\text {ST }}$ ed., Beirut: World of Books, 1997, pp.89.

[15] I. Goldziher, History of Grammar among the Arabs, pp. 35.

[16] S. Ê. Öaif, Grammar School, pp. 80.

[17] I. ÑAqÊl, "Explain the Son of Aqil," vol. 1, pp. 459.

[18] I. ÑAqÊl, "Explain the Son of Aqil," vol. 1, pp. 167.

[19] A. SuyËİÊ, Flowered in the Science of Language \& Types of Grammar Schools, 1st ed., vol. 1, Fuad Ali ManÎËr, Beirut: World of books, 1998, ch.7, pp. 114.

[20] I. Goldzihar, History of Grammar among the Arabs, pp. 35.

[21] Sibawayh, The Book, vol. 3, pp. 477-478.

[22] I. ÑAqÊl, "Explain the Son of Aqil," vol. 1, pp.500.

[23] A. Mubarrid, The Brief, 2nd ed. Hassan Hamad, Ed. Beirut: World of books, 1999, vol. 3, pp. 234; al-AshmËnÊ Explain Ashmouni on Poem of Son of Malik, Cairo: DÉr al-Kutub al-ÑArabiyah, 1918, vol. 1, pp. 245.

[24] A. AshmËnÊ, "Explain Ashmouni on Poem of Son of Malik," Manuscript, vol. 3, pp. 161-162.

[25] Sibawayh, The Book, vol. 3, pp. 381.

[26] Sibawayh, The Book, vol. 2, pp. 185.

[27] A. S. Ëİ̈E, Order Aluaah In The Layers Linguistic \& Grammarians, 1st ed., 2004, ch. 18, vol. 2, pp. 185.

[28] M. Ê. MakhzËmi, School of Kufah \& Its`s Approach, pp. 115.

[29] A. RÉİi, A Complacent Explaination, 1st ed., vol. 2, ch. 2, pp. 311.

[30] I. HishÉm, Singer Labeeb, 1st ed., M. M. A. Hamed, ed. vol.1, pp. 314.

[31] S. J. Zubayr, Measurement in Arabic Grammar, ch. 2, pp. 76. 
[32] M. MakhzËmi, "School of Kufah \& Its`s Approach,” ch. 2, pp. 394.

[33] S. Ê. Öaif, Grammar School, pp. 157.

[34] I. Golziher, History of Grammar among the Arabs, pp. 23-33.

[35] I. ÑAqÊl, Explain the Son of Aqil, vol. 1, pp. 383.

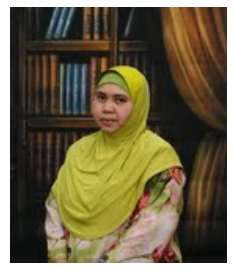

Solehah Hj. Yaacob has got the Ph.D. degrees from the International Islamic University Malaysia. She has 16 years working experience on specialization in philosophy of Arabic Grammar. Her Articles published in: Majma' Lughawy Jordan, Journal of Social Sciences,F Singapore, Common Ground Melbourne Australia, at-Tajdid IIUM, Kulliyah Darul Ulum, Egypt, Majallah al-Mahakkamah al-MaÑÉrif al-JÉmiÑyah, Anbar Iraq, Sino English Teaching New York USA, Journal of Asia IIUM, Journal Linguistic Al-adÉd, Malaya
University, etc.

She presented papers in her field in various countries such as, Cairo Egypt, New York USA, Tehran Iran and in Istanbul Turkey. She achieved the highest score evaluated by Common Ground, Melbourne Australia in 2009, for her paper presented in Istanbul, and best paper award in 2008 in Tehran, Iran. 